Goldschmidt 2021 Abstract

https://doi.org/10.7185/gold2021.6773

\section{Do ancient brines trapped as fluid inclusions in unconformity-related deposits differ from present-day porewaters in Triassic aquifers of the Paris basin?}

LOUISE LENOIR ${ }^{1}$, THOMAS BLAISE ${ }^{1}$, DIANA CHOURIO$\mathrm{CAMACHO}^{2}$, ALEXANDRE TARANTOLA ${ }^{3}$, PIERRE AGRINIER $^{4}$, ANTONIN RICHARD ${ }^{5}$, THOMAS

RIGAUDIER $^{6}$, GAEL MONVOISIN ${ }^{1}$, GERARD BARDOUX ${ }^{7}$, BENJAMIN BRIGAUD ${ }^{1}$ AND JOCELYN BARBARAND ${ }^{1}$

${ }^{1}$ Université Paris-Saclay, CNRS, GEOPS

${ }^{2}$ Université PSL, MINES ParisTech, Centre de Géosciences

${ }^{3}$ Université de Lorraine, CNRS, CREGU, GeoRessources

Laboratory

${ }^{4}$ Université de Paris, Institut de Physique du Globe de Paris, CNRS UMR 7154

${ }^{5}$ Université de Lorraine - CNRS - CREGU - GeoRessources

${ }^{6}$ Université de Lorraine, Centre de Recherche Pétrographiques et Géochimiques, UMR 7358 CNRS

${ }^{7}$ Université de Paris, Institut de Physique du Globe de Paris, CNRS

Presenting Author: louise.lenoir@universite-paris-saclay.fr

In this study, we discuss the physical and chemical properties of primary fluid inclusions trapped in geodic fluorite crystals dated at $130 \mathrm{Ma} \pm 15 \mathrm{Ma}$ [1] from two F-Ba ore deposits located above the basement/sediment unconformity in the southeastern edge of the Paris basin. Microthermometry reveals minimal trapping temperatures of ca. $110^{\circ} \mathrm{C}$, while salinity averages 18 $\mathrm{wt} \%$ eq. $\mathrm{NaCl}$, calcium chloride salts being dominant. Oxygen and hydrogen stable isotope composition of fluid inclusions measured by micro-equilibration indicate the contribution of meteoric waters. Major dissolved ions in fluid inclusions were measured using a bulk crush-leach method [2]. $\mathrm{Cl} / \mathrm{Br}$ ratios show that salinities were acquired through the evaporation of seawater beyond halite precipitation. However, $\delta^{37} \mathrm{Cl}$ values are lower than the expected composition of an evaporated seawater. We propose that fluorite precipitated from the mixing of two fluids: 1) an evaporated seawater expelled during the compaction of sediments, diluted by 2) meteoric waters infiltrated along the basement fractures.

Present-day deep groundwaters flowing through Triassic aquifers in the central part of the Paris basin $[3,4]$ display comparable chemical and isotopic compositions with those measured in fluid inclusions trapped in $130 \pm 15 \mathrm{Ma}$ fluorite crystals. This indicates that the salinity of present-day brines may also originate from ancient evaporation of seawater. Similar brines, with elevated concentration in $\mathrm{Ca}$ and $\mathrm{F}$, were also documented in the fractured basement in the central Paris Basin [5]. The upward migration of these fluids through fractures in the crystalline basement and the associated pressure/temperature drop leads to fluorite precipitation, as witnessed in the presentday outcropping southeastern edge of the basin.

[1] Gigoux et al. (2015) Miner Deposita, vol. 50, No. 4, 455-
463. [2] Gleeson et al. (2003) Book chapter, 32, 233-247. [3] Worden and Matray (1995) Basin Research, vol. 7, No. 1, 53-66. [4] Millot et al. (2011) Chem Geo, vol. 283, No. 3-4, 266-241. [5] Boulègue et al. (1990) BSGF, vol. VI, No. 5, 789-795. 